ENCYCLOPEDDIE Encyclopédie berbère

BERBERE

1 | 1984

1 | Abadir - Acridophagie

Abū Tašfin

(Voir 'Abd el-Wadides)

C. El Briga

\title{
OpenEdition
}

Journals

Édition électronique

URL : http://journals.openedition.org/encyclopedieberbere/800

DOI : $10.4000 /$ encyclopedieberbere.800

ISSN : 2262-7197

Éditeur

Peeters Publishers

Édition imprimée

Date de publication : 1 novembre 1984

Pagination : $91-92$

ISBN : 2-85744-201-7

ISSN : $1015-7344$

Référence électronique

C. El Briga, «Abū Tašfin », Encyclopédie berbère [En ligne], 1 | 1984, document A29, mis en ligne le 01 décembre 2012, consulté le 05 octobre 2020. URL : http://journals.openedition.org/ encyclopedieberbere/800 ; DOI : https://doi.org/10.4000/encyclopedieberbere.800

Ce document a été généré automatiquement le 5 octobre 2020.

(c) Tous droits réservés 


\title{
Abū Tašfin
}

\author{
(Voir 'Abd el-Wadides)
}

\section{El Briga}

Abū Tašfin Ir (718/1318-735/1337) s'empara du trône de son père Abū Hammū Mūsa après l'avoir fait assassiner. Il commença son règne en exilant en Espagne un grand nombre de ses parents afin de s'assurer la plénitude du pouvoir. Assez peu dévot, mais très attaché aux arts, il fit construire de nombreux monuments à Tlemcen dont il ne subsiste que le Grand Bassin.

Il subit l'influence de Hilāl, un Catalan converti à l'Islam, qui devint son confident et semble avoir dirigé les affaires du royaume. Le règne de Abū Tašfin marque une volonté très ferme d'extension vers l'Est: des expéditions sont envoyées contre les Hafsides dans l'intention de s'emparer de Bougie et de Constantine, mais une alliance opportune des Hafsides et des Mérinides contraint Abū Tašfin à une position désormais défensive. Abū l'Hassan le souverain mérinide s'empare en 737/1337 de Tlemcen; Abū Tašfin meurt au cours des combats et le royaume abd-el Wadide, devenu une province mérinide, disparaît pour quelques années.

4 Abū Tašfin II (né en 752/1351, mort en 795/1393) régna un peu plus de trois ans sur le trône abd-el Wadide restauré par son père Abū Hammū II. Elevé à Nédroma auprès du dévot Abū Yaqūb, son grand-père, Abū Tašfin II fut envoyé à Fès comme otage. Revenu à Tlemcen en $760 / 1359$, Abū Tašfin se révolte contre son père et le fait prisonnier à Oran. A partir de ce moment une longue suite de péripéties aventureuses opposent le père et le fils. Abū Tašfin se réfugie un moment à Fès tandis que son père rentre triomphant à Tlemcen (790/1388), un an plus tard Abū Tašfin, à la tête d'une armée mérinide écrase les troupes de Abū Hammū qui est tué au cours du combat. Abū Tašfin devenu roi n'est plus qu'un vassal des Mérinides de Fès. Ses trois années de règne, marquées par l'assassinat de ses frères, furent cependant prospères.

Encyclopédie berbère, 1 | 1984 


\section{BIBLIOGRAPHIE}

Voir 'Abd el-Wadides.

INDEX

Mots-clés : Algérie, Biographie, Moyen Âge 